\title{
The Determinant Factors Of Entrepreneurial Orientation In Embroidery Small Enterprises In Aceh, Indonesia
}

\author{
Yuli Kusdiarni \\ Student of Doctorate, \\ Program in Development Extention/Community Empowerment \\ Study Program of Sebelas Maret University \\ Darsono \\ Development Extention/Community Empowerment \\ Study Program of Sebelas Maret University \\ Sapja Anantanyu \\ Development Extention/Community Empowerment \\ Study Program of Sebelas Maret University \\ Mohd. Harisudin \\ Development Extention/Community Empowerment \\ Study Program of Sebelas Maret University
}

\begin{abstract}
The entrepreneurial orientation owned by embroidery enterpreneurs is influenced by many factors. Some of these factors include personal creativity, internal environment, external environment and stakeholders. For this reason, this research aims at testing empirically and analyzing the influence of personal creativity, internal environment, external environment and stakeholders on entrepreneurial orientation. This research covers 7 regencies/municipalities in Aceh Province. 200 embroidery enterpreneursare proportionally sampled from these 7 regions for this research. The research results indicate that personal creativity, internal environment, external environment and stakeholders have influence on entrepreneurial orientation.
\end{abstract}

Keywords: entrepreneurial orientation, influence, personal creativity, internal environment, external environment, stakeholders, embroidery

\section{INTRODUCTION}

The embroidery crafts entrepreneurs in Aceh utilize their expertise to produce embroidery in the form of souvenirs. The most well-known souvenir from this province is bag, hence every tourist visiting the place would spare their time to buy it. Additionally, these souvenirs also include wallets, peci (cap), clothing, sajadah (prayer rug), household goods and other accessories.

These embroidery crafts are highly specific and have their own characteristics since the motif design applied to the materials are widely varied. The most well-known motif design is pinto Aceh and some other motif designs such as 'tulak angen', 'bungong jeumpa', 'rincong', 'emun berangkat', 'pucok rebong' and so forth are also attractive. It is also not uncommon that a product has more than one motif designs.

A worker can produce 5-10 products every day, depending on the size and difficulty level of the motif applied to the souvenir materials. It will even take them more time if they have to 
combine many thread colors into a motif. All of these embroidery jobs are done manually and often without the motif design being drawn on the materials.

As a small enterprise, these embroidery craft businesses will operate in a constantly changing business environment which is frequently beyond the entrepreneurs' control at all. The changes to this business environment give birth to various opportunities and threats for entrepeneurs in managing their businesses. For this reason, entrepreneurs are demanded to have the ability to find opportunities and to minimize any existing threats.

Dhewanto et al. (2019) suggests that entrepreneurs must be capable of monitoring and maintaining their businesses to prevent themselves from being negatively affected by the uncertainty of their business environment. One of the attempts they can take to do it is by understanding their business environment. This is because understanding their business environment would allow them to see and predict potential opportunities and threats to occur. In a tightly competitive business environment, only those capable of producing novel ideas and/or unique products or applications will survive (Taha et al., 2016). Personal creativity is another method for embroidery enterpreneurs to survive the highly competitive business environment. Personal creativity can lead to creative ideas which allow entrepreneurs to reach success even in a constantly changing business environment since it will give new ideas for products, be it goods or services to fulfill the ever developing market needs. Creativity also leads to new ideas which will both efficiency and productivity.

Developing these embroidery crafts themselves has been a strategy to increase the regional economy. For this purpose, a collaboration between stakeholdersis needed in order to establish a synergy which will allo the acceleration of small enterprises' growth and development.

In addition, entrepreneurs requires entrepreneurial orientation to deal with changes to their environment and to implement the ideas resulting from the creativity they own. When entrepreneurs have this entrepreneurial orientation, they will have a competitive advantage which distinguish them from other entrepreneurs (Wiklund and Shepherd, 2005).

From these phenomena, this research aims to: a) discover whether or not there is a simultaneous influence ofpersonal creativity, internal environment, external environmentand stakeholders on entrepreneurial orientation; b) figure out whether or not there is a partial influence of personal creativity, internal environment, external environment and stakeholders on entrepreneurial orientation; and c) find out to what extent these variables correlate.

\section{Entrepreneurial orientation}

\section{REVIEW OF LITERATURE}

Miller's (1983) operating concept of entrepreneurial orientation is an orientation to strive to be the first in product innovation in the market, brave enough to take the risk and to take proactive actions to be able to defeat competitors. Lumpkin and Dess (1996) also add that entrepreneurial orientation is the processes, practices, and decision making which cause newcomers to occur (for example by entering a new or old market or launching new products). Meanwhile, Messeghem (2003) suggests that entrepreneurial orientation is a company's ability in seeing a new business opportunity.

Zahra (1993) measures entrepreneurial orientation from three dimensions, namely proactiveness, risk taking, and innovativeness. Lumpkin and Dess (1996) adds two dimensions, i.e. autonomy and agressive competition to the characteristics of entrepreneurial orientation. 
Furthermore, Messeghem (2003) mentions five indicatorsin seeing this entrepreneurial orientation, namely standardization, formalization, specialization, planning and control system, external information system. The higher these indicators the stronger the entrepreneurial orientation of a company. Atuahene-Gima \& Ko (2001) in Chang (2015) suggest that entrepreneurial orientation involves innovation values in organization, risk-taking management, and proactiveness to produce organization learning and knowledge in developing new products. The success of a new product will determine the organization's performance such as sales and profit.

\section{Personal Creativity}

According to Harris (1998) in Okpara (2007) and Gurteen (1998) in Suryana (2013), creativity is the ability to generate ideas, transform ideas into actions through selection, to create a new form, to produce through imaginative skills, and to bring into existence something new. Creativity itself does not occur just like that in an organization or within a person self. An entrepreneur should be capable of creating an environment which can nurture creativity, both for himself/herself and for his/her employees. This is because new ideas are easy-to-break creations, yet the right organizational environment could encourage people to develop and manage them (Zimmerer and Scarborough, 2005).

Personal creativity basically requires expertise, creative thinking skills and intrinsic task motivation. The higher each of these components, the higher the creativity would be (Amabile, 1998; Robbins and Judge, 2008). Moreover, Zimmerer and Scarborough (2005) state that creative processes can be improved using brainstroming, mind-mapping, and rapid prototyping. An entrepreneur can use several methods to help generate and test new ideas, including: focus groups, brainstroming, and problem inventory analysis (Hisrich et.al, 2008).

\section{Business Environment}

Porter (1980) suggests that business environment can be divided into two categories, i.e. internal and external environments. Business environmentis the total sum of all external and internal factors which influences the situation of a business. Here, these external and internal factors might influence each other and cooperate to influence a business.

Porter (1980) states that a company's external environment is the factor which,while indirectly,can still influence the company itself, its activities, and its strategy.This external environment is better known as Porter's (1994) five forces model, consisting of such risks as potential competitors penetrating (the market), supplier power, buyer power, substitute goods availability, and inter-company competition.

In addition to having to deal with external environment, an entrepreneur should also be capable of managing their internal environmentwell. Porter (1980) suggests that internal environment is the one within a company. This internal environment include such aspects as: finance, human resources, marketing, operation and other aspects of the company. According to Munizu (2010) the internal environment factors which influence the performance of micro and small enterprises include: human resources, business finance, technical and operating aspects, and market and marketing aspects.

\section{Stakeholders}

Stakeholders, according to Bourne (2005), are individuals or groups which have some interests, have some rights and ownership in a project or an organization, as well as all parties which can contribute or may be affected by the project or organization's products. Also, 
Freeman (2010) defines stakeholders as the groups or individuals which can influence and or be influenced by a certain goal achievement.

Stakeholders, in Carayannis and Campbell's (2009) opinion, are Quadruple Helix, i.e. focusing on the relationship between university, business, government and civil society. Karsidi and Irianto (2005) in Karsidi (2007) suggest stakeholders who can give a contribution to the advancement of small and medium enterprises, namely: the small and medium enterprises themselves, groups/cooperatives, business association, financial institutions, market, government, and colleges. Meanwhile, Slamet et al. (2016) propose Penta Helix, i.e. a collaboration of roles of Academy, Bussines, Commuity, Goverment, and Media.

This research uses the entrepreneurial orientation variable as suggested by Lumpkin and Dess (1996) who measure it from the five dimensions, namely proactiveness, risk taking, innovativeness, autonomy and aggresive competition. For the personal creativity variable, the measurement dimensions are taken from Amabile (1998), which include expertise, creative thinking skills and intrinsic task motivation. The external environment variable uses the dimensions proposed by Porter (1994) which consist of risk of potential competitor coming, supplier's power, buyer's power, substitute goods availability, and inter-company competition. Meanwhile, for the internal environment variable, the dimensions used are suggested by Munizu (2010) consisting of human resources, business finance, technical and operating aspects, and market and marketing aspects. Finally, for the stakeholders variable, this research uses the Penta Helix dimension, i.e. the dimensions suggested by Carayannis and Campbell (2009) and Karsidi and Irianto (2005) in Karsidi (2007) are combined, including: government, academics, entrepreneurs, association and financial institutions.

\section{RESEARCH METHOD}

The population in this research are entrepreneurs from embroidery industry from 7 regencies/municipalities in Aceh. The sample is divided for each research regency/municipality using proportional sampling, a sampling technique which can be used in both stratified, area and cluster populations (Bugin, 2013) and the sample is taken using simple random sampling, where members of a population are taken as sample randomly regardless the strata within that population (Sugiyono, 2013). The data are collected by distributing questionnaires to embroidery enterpreneurs. The data are processed using SPSS 22 , the confidence level is $95 \%$ and a hypothesis is accepted is its significance value is less than 0.05 .

\section{Result of Multiple Linear Regression Analysis}

\section{RESULTS AND DISCUSSION}

To see both the simultaneous and partial influences of personal creativity, internal environment, external environment and stakeholders variables on entrepreneurial orientation, the diagram model of multiple linear regression analysisis: 
Figure 1. Diagram Model of Multiple Linear Regression Analysis

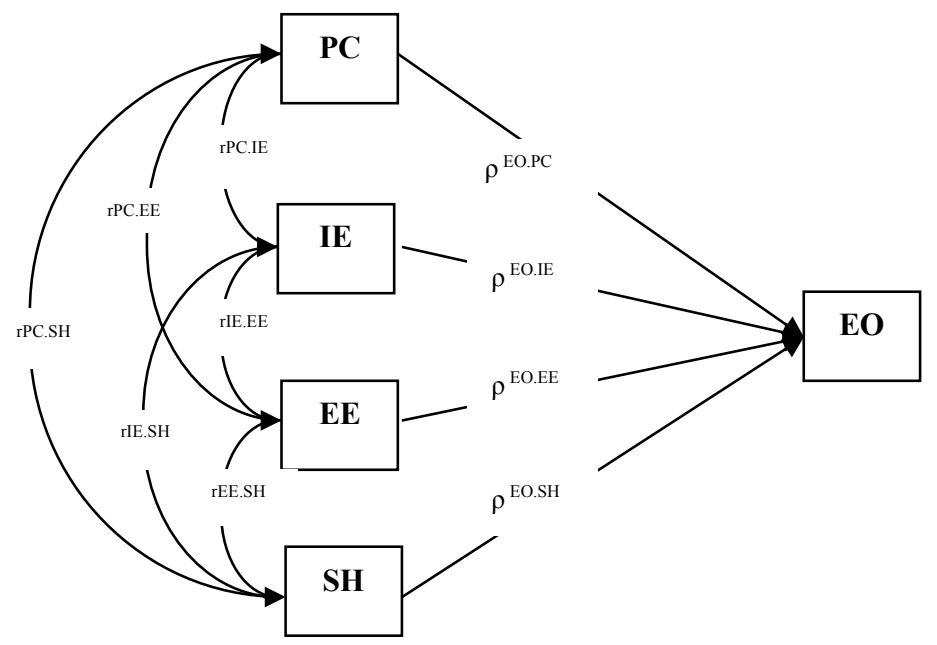

Where PC is personal creativity, IE is internal environment, EE is external environment, $\mathrm{SH}$ is stakeholders, and EO is entrepreneurial orientation.

In this section, the analysis is divided into three parts, a) to see the simultaneous influence of personal creativity, internal environment, external environment and stakeholders on entrepreneurial orientation; b) to see the partial influence of personal creativity, internal environment, external environment and stakeholders on entrepreneurial orientation; and c) to see the extent of correlation between these variables.

The formulation of equation for the diagram model of multiple linear regression analysis in Figure 1 above can be written as follows:

$$
\mathrm{Y}=c+\rho E O \cdot C P C P+\rho E O \cdot I E I E+\rho E O \cdot E E . \mathrm{EE}+\rho E O \cdot S H S H
$$

Figuring out the simultaneous influence of personal creativity, internal environment, external environment and stakeholders on entrepreneurial orientation

To analyze the simultaneous influence of personal creativity, internal environment, external environment and stakeholders on entrepreneurial orientation, the following Table 1 can be referred to:

Table 1.Result of Test of Influence of Internal Environment, External Environment and Personal Creativity on Entrepreneurial orientation

\begin{tabular}{|c|c|c|c|c|c|c|}
\hline Description & $\begin{array}{c}\text { Determination } \\
\text { coefficient } \mathbf{R}^{\mathbf{2}}\end{array}$ & $\begin{array}{c}\text { Adjusted } \\
\mathbf{R}^{\mathbf{2}}\end{array}$ & $\begin{array}{c}\text { Std. Error of } \\
\text { the Estimate }\end{array}$ & $\mathbf{F}$ & Sig. & $\boldsymbol{\alpha}$ \\
\hline Equation 1 & 0.453 & 0.442 & 6.074192 & 40.362 & 0.000 & 0.05 \\
\hline Decision & H1 is accepted
\end{tabular}

Source: Primary data, processed (2018)

Ghozali (2005) states that to measure the extent of contribution of an independent variable to a dependent variable, a determination coefficient $\left(\mathrm{R}^{2}\right)$ can be used. This determination coefficient has a value ranging between 0 and 1 . The closer it is to one, the better the independent variable'sability in explaining the dependent variable and the closer the determination coefficient value to 0 , the lesser the influence of the independent variables on the dependent variable. This research uses Adjusted $\mathrm{R}^{2}$ since, according to Santoso (2005), for a regression with more than two independent variables, Adjusted $\mathrm{R}^{2}$ shall be used as a determination coefficient. 
Table 1 shows that the value of Adjusted $R^{2}$ is 0.442 . This value means that the influence of personal creativity, internal environment, external environment and stakeholders simultaneously on entrepreneurial orientation is 0.442 . The remaining 0.558 is influenced by factors other than these four variables.

The regression model feasibility test is done in two ways. Firstly, it is done by comparing the value of $\mathrm{F}$ found by the research against the $\mathrm{F}$ table. The second way is by comparing the value of significance rate (sig) against the result of calculation.

Using the first method, i.e. comparing the value of $\mathrm{F}$ found by the research against $\mathrm{F}$ table. The value of $\mathrm{F}$ found in this research from SPSS is 40.362. Meanwhile, the degree of independence is the number of variables $-1=5-1=4$; and the denumerator $=$ number of sample $-4=196$. Using these values, the value of $\mathrm{F}$ tableis 2.42. Furthermore, based on the calculation of significance rate which is $0.000<0.05$, then the $\mathrm{H}_{0}$ is rejected and $\mathrm{H}_{1}$ is accepted. This means personal creativity, internal environment, external environment and stakeholders have an influence on entrepreneurial orientation. Therefore, the estimated regression model is feasible.

Table 2. Statistic Description of Research Variables

\begin{tabular}{|l|c|c|c|c|}
\hline & Mean & Median & $\begin{array}{c}\text { Std. } \\
\text { Deviasi }\end{array}$ & N \\
\hline $\begin{array}{l}\text { Entrepreneurial orientation } \\
\text { (EO) }\end{array}$ & 82.94843 & 81.39400 & 8.129428 & 200 \\
\hline Personal Creativity (PC) & 60.39535 & 58.96200 & 5.892431 & 200 \\
\hline Internal Environment (IE) & 63.51087 & 62.76150 & 7.407218 & 200 \\
\hline External Environment (EE) & 76.46548 & 78.69600 & 8.737700 & 200 \\
\hline Stakeholders (SH) & 73.72438 & 72.09700 & 12.246345 & 200 \\
\hline
\end{tabular}

Source: Primary data, processed (2018)

The value of Standard Error of Estimate in Table 1 is 6.074192. According to Sawono (2013), this value is used to assess the feasibility of predictors (independent variables) in relation to the dependent variable with a condition: if the value of nilai Standard Error of Estimate < value of standard deviation of dependent variable, then the independent variables used to predict the dependent variable have been feasible.

Judging from the results in Table 1 and Table 2 above, then:

- Standard Error of Estimate (6.074192) < Standard deviation of entrepreneurial orientation variable (8.129428).

- Standard Error of Estimate (6.074192) > Standard deviation of personal creativity variable (5.892431).

- Standard Error of Estimate (6.074192) < Standard deviationof internal environment variable (7.407218).

- Standard Error of Estimate (6.074192) < Standard deviationof external environment variable (8.737700).

- Standard Error of Estimate (6.074192) < Standard deviation of stakeholders variable (12.246345).

From the fact above, 1 predictor is found to be invalid, i.e. the personal creativity variable, since the value of Standard Error of Estimate is greater than its standard deviation. However, in the output above, the value of Standard Error of Estimate (6.074192) is lesser than the value of standard deviation for the dependent variable, entrepreneurial orientation (8.129428). It means the independent variables personal creativity, internal environment, external 
environmentand stakeholders have been feasible to be predictor for the dependent variable entrepreneurial orientation.

Finding out the partial influence of personal creativity, internal environment, external environment and stakeholders variables on entrepreneurial orientation

The partial influence of personal creativity, internal environment, external environment and stakeholders variables on entrepreneurial orientation can be seen from the value of unstandardized coefficients (B) in Table 3.

Table 3. Coefficient Values of Personal Creativity, Internal Environment, External Environment and Stakeholderson Entrepreneurial orientation

\begin{tabular}{|l|c|c|c|c|}
\hline \multicolumn{1}{|c|}{ Model } & $\begin{array}{c}\text { Unstandardized } \\
\text { Coefficients } \\
\text { (B) }\end{array}$ & Nilai t & Sig. & $\boldsymbol{\alpha}$ \\
\hline Constant & 21.058 & 3.580 & 0.000 & 0.05 \\
\hline Personal Creativity & 0.286 & 3.501 & 0.001 & 0.05 \\
\hline Internal Environment & 0.219 & 2.552 & 0.011 & 0.05 \\
\hline External Environment & 0.218 & 3.377 & 0.001 & 0.05 \\
\hline Stakeholders & 0.191 & 3.740 & 0.000 & 0.05 \\
\hline
\end{tabular}

Source: Primary data, processed (2018)

This table shows the regression equationto discover the constant value and hypothesis testing of regression coefficient significance. The constant value of unstandardized coefficients found in this research is 21.058. This value takes the form of constant value, indicating: the magnitude of entrepreneurial orientation when the personal creativity, internal environment, external environment and stakeholders are equal to 0.

The partial test as shown by Table 3 indicate the regression coefficient valueof personal creativity on entrepreneurial orientation, the regression coefficient value of internal environment on entrepreneurial orientation, the regression coefficient value of external environment on entrepreneurial orientation and the regression coefficient value of stakeholders on entrepreneurial orientation. The research hypothesis is formulated with the following statistic hypothesis:

$\mathbf{H}_{\mathbf{0}}=$ personal creativity/internal environment/external environment/ stakeholders has no influence on entrepreneurial orientation

$\mathbf{H}_{\mathbf{1}}=$ personal creativity/internal environment/external environment/ stakeholders has an influence on entrepreneurial orientation

Furthermore, to figure out the significance, a comparison is made between the probability value of 0.05 with the sig probability value with the bases for making decisions as follows:

- If the probability value of 0.05 is less than or equal to sig probability value or $(0.05 \leq$ sig), then $\mathrm{H}_{0}$ is accepted and $\mathrm{H}_{1}$ is rejected, meaning it is insignificant.

- If the probability value of 0.05 is greater than or equal to sig probability value or $(0.05 \geq$ sig), then $\mathrm{H}_{0}$ is rejected and $\mathrm{H}_{1}$ is accepted, meaning it is significant.

1) Influence of personal creativity on entrepreneurial orientation.

From the calculation result, it is found that the value of $t$ in this research is 3.501 and significance value is 0.001 . Meanwhile, the value of $t$ table with a significance rate of 0.05 and degree of independence $(\mathrm{DK})=\mathrm{n}-4=200-4=196$, is found to be 1.97214 . 
The value of $t$ found in this research of $3.501>t$ table of 1.97214 , hence $\mathrm{H}_{0}$ is rejected and $\mathrm{H}_{1}$ is accepted. This means personal creativity has an influence on entrepreneurial orientation. The extent of influence ofpersonal creativityon entrepreneurial orientation is equal to the value of Beta, i.e. 0.286.

2) Influence ofinternal environment on entrepreneurial orientation.

From the calculation result, it is found that the value of $t$ in this research is 2.552 and the significance value is 0.011 . Meanwhile, the value of $t$ table with a significance rate 0.05 and degree of independence $(\mathrm{DK})=\mathrm{n}-4=200-4=196$, is found to be 1.97214 .

The value of $t$ found in this research of $2552>t$ tableof 1.97214, thus $\mathrm{H}_{0}$ is rejected and $\mathrm{H}_{1}$ is accepted. This means internal environment has an influence on entrepreneurial orientation. The extent of influence of internal environmenton entrepreneurial orientation is equal to the value of Beta, i.e. 0.219 .

3) Influence of external environment on entrepreneurial orientation.

From the calculation result, it is found that the value of $t$ in this research is 3.377 and the significance value is 0.001 . Meanwhile, the value of $t$ table with a significance rate 0.05 and degree of independence $(\mathrm{DK})=\mathrm{n}-4=200-4=196$, is found to be 1.97214 .

The value of $t$ found in this research of $3.377>t$ table of 1.97214 , therefore $\mathrm{H}_{0}$ is rejected and $\mathrm{H}_{1}$ is accepted. This means external environment has an influence on entrepreneurial orientation. The extent of influence of external environment on entrepreneurial orientation is equal to the value of Beta, i.e. 0,218.

4) Influence of stakeholders on entrepreneurial orientation

From the calculation result, it is found that the value of $t$ in this research is 3.740 and the significance value is 0.001 . Meanwhile, the value of $t$ table with a significance rate of 0.05 and degree of independence (DK) $=n-4=200-4=196$, is found to be 1,97214 .

The value of $t$ found in this research of $3,740>t$ table of 1,97214 , hence $\mathrm{H}_{0}$ is rejected and $\mathrm{H}_{1}$ is accepted. This mean stakeholders have an influence on entrepreneurial orientation. The extent of influence of stakeholders on entrepreneurial orientation is equal to the value of Beta, i.e. 0.191.

\section{Discovering the correlation between variables}

The correlation analysis among personal creativity, internal environment, external environment and stakeholders variables can be seen in the result of SPSS calculation as shown below: 
Table 4 Result of Correlation among Variables

Correlations

\begin{tabular}{|c|c|c|c|c|c|}
\hline & & $\begin{array}{l}\text { Personal } \\
\text { creativity }\end{array}$ & $\begin{array}{c}\text { Internal } \\
\text { environment }\end{array}$ & $\begin{array}{c}\text { External } \\
\text { environment }\end{array}$ & Stakeholders \\
\hline \multirow[t]{3}{*}{$\begin{array}{l}\text { Personal } \\
\text { creativity }\end{array}$} & $\begin{array}{l}\text { Pearson } \\
\text { Correlation }\end{array}$ & 1 & & & .026 \\
\hline & Sig. (2-tailed) & & .000 & .773 & .710 \\
\hline & $\mathrm{N}$ & 200 & 200 & 200 & 200 \\
\hline \multirow[t]{2}{*}{$\begin{array}{l}\text { Internal } \\
\text { environment }\end{array}$} & $\begin{array}{l}\text { Pearson } \\
\text { Correlation }\end{array}$ & & 1 & $.520^{* *}$ & \\
\hline & $\begin{array}{l}\text { Sig. (2-tailed) } \\
\mathrm{N}\end{array}$ & $\begin{array}{l}.000 \\
200\end{array}$ & 200 & $\begin{array}{l}.000 \\
200\end{array}$ & $\begin{array}{l}.000 \\
200\end{array}$ \\
\hline \multirow{4}{*}{$\begin{array}{l}\text { External } \\
\text { environment }\end{array}$} & Pearson & & & 1 & \\
\hline & Correlation & & $.5 \angle 0$ & & \\
\hline & Sig. (2-tailed) & .773 & .000 & & .000 \\
\hline & $\mathrm{N}$ & & 200 & 200 & 200 \\
\hline \multirow[t]{3}{*}{ Stakeholders } & $\begin{array}{l}\text { Pearson } \\
\text { Correlation }\end{array}$ & .026 & $.631^{* *}$ & $.612^{* *}$ & 1 \\
\hline & Sig. (2-tailed) & .710 & .000 & .000 & \\
\hline & $\mathrm{N}$ & 200 & 200 & 200 & 200 \\
\hline
\end{tabular}

**. Correlation is significant at the 0.01 level (2-tailed).

Source : Primary data, processed (2018)

To interpret these values, the following criteria are used:

$$
\begin{array}{ll}
0-0.25 & : \text { Very weak correlation (considered inexistent) } \\
>0,25-0,50 & : \text { Fair correlation } \\
>0,50-0,75 & : \text { Strong correlation } \\
>0,75-1 & : \text { Very strong correlation }
\end{array}
$$

1) The correlation between personal creativity and internal environment is 0.344, meaning that the correlation between personal creativity and internal environment fairly strong and in the same direction (since the result is positive). Being in the same direction means that if the personal creativity is high, then the internal environment is also high. The correlation of these two variables is significant since the significance value is $0.000<0.05$.

2) The correlation between personal creativity and external environment is -0.020 , meaning that the correlation between personal creativity and external environment very weak and not in the same direction (since the result is negative). Being not in the same direction means that if the personal creativity is high, then the external environment will be low. The correlation of these two variables is insignificant since the significance value is $0.773>0.05$.

3) The correlation between personal creativity and stakeholders is 0.026 , meaning that the correlation between personal creativity and stakeholders is very weak yet it is in the same direction (since the result is positive). Being in the same direction means that if the personal creativity is high, then the stakeholders is also high. The correlation of these two variables is insignificant since the significance value is $0.710>0.05$.

4) The correlation between internal environment and external environment is 0.520 , meaning that the correlation between the internal environment and the external environment is strong and in the same direction (since the result is positive). Being in the same direction means that if the internal environment is high, then the external environment is also high. The correlation of these two variables is significant since the significance value is $0.000<0.05$. 
5) The correlation between internal environment and stakeholders is 0.631 , meaning that the correlation between the internal environment and the stakeholders is strong and in the same direction (since the result is positive). Being in the same direction means that if the internal environment is high, then the stakeholders is also high. The correlation of these two variables is significant since the significance value is $0.000<0.05$.

6) The correlation between external environment and stakeholders is 0.612 , meaning that the correlation between the external environment and the stakeholders is strong and in the same direction (since the result is positive). Being in the same direction means that if the external environment is high, then the stakeholders is also high. The correlation of these two variables is significant since the significance value is $0.000<0.05$.

Based on the the extent of influence of personal creativity, internal environment, external environment and stakeholders variables on the entrepreneurial orientation as seen in Table 3 and the extent of correlation between variables as shown in Table 4, a multiple linear analysis diagram model can be drawn as follows:

Figure 2.Result of Diagram Model of Multiple Linear Regression Analysis

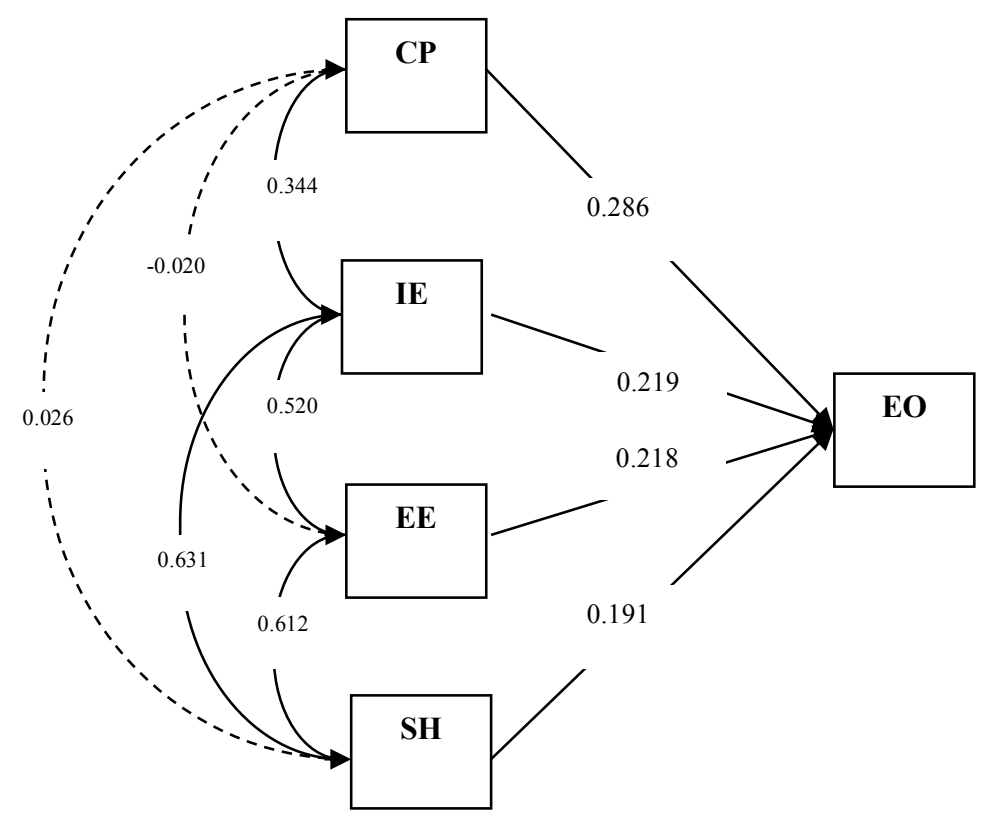

Thus, the equation becomes:

$$
\mathrm{Y}_{1}=21.058+0.286 \mathrm{CP}+0.219 \mathrm{IE}+0.218 \mathrm{EE}+0.191 \mathrm{SH}
$$

\section{DISCUSSION}

The simultaneous influence of personal creativity, internal environment, external environment and stakeholders variables on entrepreneurial orientation is 0.442 and the remaining 0.558 is influenced by factors other than these four variables. From the regression model, it can be seen that the value $\mathrm{F}$ found in this research of $40.362>\mathrm{F}$ table 2.42, and the research significance valueof $0.000<0.05$, therefore it can be said that personal creativity, internal environment, external environment and stakeholders variables have an influence on entrepreneurial orientation. In other words, the estimated regression model is feasible.

Based on the model result in Figure 2, personal creativity variable has a positive influence on entrepreneurial orientation with a regression coefficient valueof 0.286 and significance valueof 0.001. This explains that the higher the personal creativity of an embroidery enterpreneur, the 
higher their entrepreneurial orientation would be. Creativity grows along with innovation, the higher the creativity, the more likely it is to create more innovations (Taha et al., 2016). This research finding is supported by Daddie et al. (2017) and Rahim et al. (2018) who find that there is a positive, strong correlation between entrepreneurial orientation and personal creativity. Daddie et al. (2017) conclude that creativityis the driving force of entrepreneurship, i.e. a creative individual is more likely to have an entrepreneurial orientation. Personal creativity in producing new ideas requires initiatives to expand these ideas into implementation or to be adopted as an innovation. For this reason, embroidery enterpreneurs need to have entrepreneurial orientation to allow their ideas to be implemented well by their employees and to be accepted by their customers.

The direct influence of internal environment variable has a positive influence on entrepreneurial orientation with a regression coefficient value of 0.219 and a significance value of 0.011 . This explains that the higher the ability of an embroidery enterpreneurs in dealing with his/her internal environment, the higher the entrepreneurial orientation would be. This research finding supports Wulandari (2009) who finds that external environment has a positive influence on entrepreneurial orientation. Saydam (2006) explains that since internal environment can be controlled organizationally by entrepreneurs, they can therefore direct them as they wish. Through entrepreneurial orientation, entrepreneurscould focus on allocating various resourcesthey own to earn long-term benefit.

External environment variable has a direct, positive influence on entrepreneurial orientation with a regression coefficient valueof 0.218 and significance value of 0.001 . This explains that the higher the ability of an embroidery enterpreneur in dealing with his/her external environment, the higher his/her entrepreneurial orientation would be. This research finding supports Wulandari (2009) who finds that external environmenthas a positive influence on entrepreneurial orientation. Since external environment cannot be controlled just like that by entrepreneurs as they wish, entrepreneurs should be capable of minimizing the strength of external environment to make their businesses survive the environment's influence (Saydam, 2006). Embroidery enterpreneurs should be able to respond to external environment influence by approaching it proactively, i.e. by anticipating any potential competitors, acting based on future market needs by ensuring the availability of raw materials supplied by suppliers, acting to satisfy their customers, anticipating the number of substitute goods and competitons occuring within the embroidery industry itself.

Stakeholders variable has a positive influence on entrepreneurial orientation with a regression coefficient valueof 0.287 and significance value of 0.000 . This explains that the higher the role played by stakeholders, the higher the entrepreneurial orientation owned by embroidery enterpreneurs. This research finding supports Ayuso et al. (2011) who find that knowledge deriving from the involvement of internal and external stakeholders contribute to the company's sustainable innovation orientation, however this knowledge should be managed by the company internally to make it transformable into new ideas for innovation. This also consistent with Dembczyk and Zaoral (2014) who find that involving stakeholders help develop innovation and innovation continuance to deal with challenges from the environment in particular. 


\section{CONCLUSION}

Based on the result of multiple linear regression analysis and discussion above, it can be concluded that:

1. Personal creativity, internal environment, external environment and stakeholders have a simultaneous influence on entrepreneurial orientation by 0.442 and the remaining 0.558 is influenced by factors other than these four variables.

2. Personal creativity, internal environment, external environment and stakeholders have a partial influence on entrepreneurial orientation.

3. The correlations between personal creativity and external environment variables and between personal creativity and stakeholders variables have a significance valueover 0.05 , meaning that they are not correlated to each other.

\section{RECOMMENDATION}

1. It is recommended that embroidery crafts entrepreneurs improve their personal creativity and ability to deal with their internal and external environments. This can be done if the entrepreneursis capable of communicating and coordinating with other stakeholders in order to obtain informationon various trainings to build capacity, knowledge on capital and business loans, market and marketing, and so forth.

2. This research uses only those aspects owned by embroidery enterpreneurs and has not yet included further environmental aspects such as economic, politic, and socio-cultural aspects. Additionally, the religiosity aspects have not been included to be determinant factors of entrepreneurial orientation considering the fact that the people of Aceh are known as religious people who up hold their customs. Therefore, future research needs to investigate it further by including these aspects.

\section{ACKNOWLEDGEMENT}

This research project is supported by the Post-Graduate Program, Sebelas Maret University and empowered by the Ministry of Research, Technology and Higher Education of the Republic of Indonesia and the Aceh Government.

\section{References:}

Amabile, T.M. (1998). How to Kill Creativity. Harvard Business Review. September-October 1998. 76-88.

Ayuso, S., Rodríguez, M.Á., García-Castro, R., \& Ariño, M.Á. (2011). Does Stakeholder Engagement Promote Sustainable Innovation Orientation?. Industrial Management \& Data Systems. 111(9). 1399-1417.

Bourne, L. (2005). Project Relationship Management and the Stakeholder Circle TM. (PhD Thesis). RMIT University. Australia (AU).

Bungin, B. (2013). Metodologi Penelitian Sosial dan Ekonomi: Format-format Kuantitatif dan Kualitatif untuk Studi Sosiologi, Kebijakan Publik, Komunikasi, Manajemen dan Pemasaran. Kencana Prenada Media Group. Jakarta.

Carayannis, E. \& Campbell, D.F.J. (2009). 'Mode 3' and 'Quadruple Helix': Toward a 21st Century Fractal Innovation Ecosystem. International Journal of Technology Management. January 2009. 46(3/4). 201-234.

Chang, C.L. (2015). Entrepreneurial Orientation, Communication Strategies, And New Product Success: A Theoretic Model. Academy of Strategic Management Journal. 14(1). 1-19.

Daddie, J.A., Tambari, J.C., \& Nwigbo, T.S. (2017). The Nexus Between Entrepreneurship Orientation and Employees' Creativity in Selected Micro-Finance Banks in Portharcourt. Advance Research Journal of MultiDisciplinary Discoveries. ISSN NO. 2456-1045. Volume: 12.0 / Chapter- XII / Issue -1 (April). 65-70

Dembczyk, A., \& Zaoral, J. (2014). Stakeholder Engagement in Sustainable Entrepreneurship and Innovation: An Exploratory Study on Start-Ups From Germany and Sweden in Renewable Energy and Energy Efficiency. Master Thesis. two-year. 30 hp. Student Umeå School of Business and Economics. Spring Semester 2014.

Dhewanto, W., Nur Rizki R, V., Yunita, F., Azzahra, S., \& Adrian, D. (2019). Internasionalisasi UKM: Usaha Kecil dan Mikro Menuju Pasar Global. Penerbit Andi. Yogyakarta.

Freeman, R.E. (2010). Strategic Management: A Stakeholder Approach. Pitman Publishing. Boston. 
Ghozali, I. (2005). Analisis Multivariate Dengan Program SPSS. Badan Penerbit UNDIP. Semarang.

Hisrich, R.D., Peters, M.P., \& Shepherd, D.A. (2008). Kewirausahaan. Edisi 7. Salemba Empat. Jakarta.

Karsidi, R. (2007). Pemberdayaan Masyarakat Untuk Usaha Kecil Dan Mikro (Pengalaman Empiris di Wilayah Surakarta Jawa Tengah). Jurnal Penyuluhan. September 2007. 3(2). 136-145

Lumpkin, G.T. \& Dess, G.G. (1996). Clarifying the Entrepreneurial Orientation Construct and Linking It To Performance. Academy of Management Review. 2(1). 135-172.

Messaghem, K. (2003). Strategis Entrepreneurship and Managerial Activities in SMEs. International Small Business Journal. 21(2). 197-212

Miller, D. (1983). The Correlates of Entrepreneurship in Three Types of Firms. Management Science. Vol. 29. 770791.

Munizu, M. (2010). Pengaruh Faktor-faktor Eksternal dan Internal Terhadap Kinerja Usaha Mikro dan Kecil (UMK) di Sulawesi Selatan. Jurnal Manajemen dan Kewirausahaan. 12(1). 33-41

Okpara, F.O. (2007). The Value of Creativity and Innovation in Entrepreneurship. Journal of Asia Entrepreneurship and Sustainability. III(2). 2-5.

Porter, M. E. (1980). Competitive Strategy: Technigues For Analizing Industries and Competitors. The Free Press. New York.

Porter, M.E. (1994). Keunggulan Bersaing, Menciptakan dan Mempertahankan Kinerja Unggul. Binarupa Aksara. Jakarta.

Rahim, A.W.P.A., Wan Ismail, W.K., Thurasamy, R., \& Rahman. I.A. (2018). The Relationship of Individual Creativity with Entrepreneurial Intention via Individual Entrepreneurial Orientation (IEO). International Journal of Innovation and Business Strategy (IJIBS). 9.(1). January 2018. 41-54

Robbins, S.P. \& Judge, T.A. (2008). Perilaku Organisasi 1. Edisi 12. Salemba Empat. Jakarta.

Santoso, S. (2005). SPSS Mengolah Data Statistik Secara Profesional. Cetakan Keempat. Penerbit PT Elexmedia Komputindo. Jakarta.

Sawono, J. (2013). Model-Model Linier dan Non Linier dalam IBM SPSS 21: Prosedur-Prosedur Alternatif Untuk Riset Skripsi. PT.Elex Media Komputindo. Jakarta.

Saydam, G. (2006). Manajemen Sumber Daya Manusia. PT. Gunung Agung. Jakarta.

Slamet, R., Nainggolan, B., Roessobiyatno, Ramdani. H., Hendriyanto. A., \& Ilma. L.L. (2016). Strategi

Pengembangan Ukm Digital Dalam Menghadapi Era Pasar Bebas. Jurnal Manajemen Indonesia. 16(2). 136-147.

Sugiyono. (2013). Metode Penelitian Kuantitatif Kualitatif dan R\&D. Alfabeta. Bandung.

Suryana. (2013). Ekonomi Kreatif. Ekonomi Baru: Mengubah Ide dan Menciptakan Peluang. Salemba Empat. Jakarta.

Taha, V.A., Sirková, M., \& Ferencová M. (2016). The Impact of Organizational Culture on Creativity \& Innovation. Polish Journal of Management Studies. 14(1). 7-17

Wiklund, J. \& Shepherd, D. (2005). Entrepreneurial Orientation and Small Business Performance: A Configurational Approach. Journal of Business Venturing. 20(1). 71-91.

Wulandari, A. (2009). Pengaruh Lingkungan Eksternal dan Lingkungan Internal Terhadap Orientasi Wirausaha dalam Usaha Meningkatkan Kinerja Perusahaan. Jurnal Pengembangan Wiraswasta. 11(2). Agustus 2009. 142152.

Zahra, S.A. (1993). A Conceptual Model of Entrepreneurship as Firm Behaviour: A Critique and Extention. Entrepreneurship Theory and Practice. 14(4). 5-22

Zimmerer, T.W. \& Scarborough N.M. (2005). Pengantar Kewirausahaan dan Manajemen Bisnis Kecil, Edisi Keempat. PT. Penebar`Swadaya. Jakarta. 